\title{
Hyperketonemia in early lactation dairy cattle: A deterministic estimate of component and total cost per case
}

\author{
J. A. A. McArt, ${ }^{*}$ D. V. Nydam, ${ }^{*}$ and M. W. Overton ${ }^{1}$ \\ *Department of Population Medicine and Diagnostic Sciences, College of Veterinary Medicine, Cornell University, Ithaca, NY 14853 \\ †Elanco Animal Health, 2500 Innovation Way, Greenfield, IN 46140
}

\begin{abstract}
The purpose of this study was to develop a deterministic economic model to estimate the costs associated with (1) the component cost per case of hyperketonemia (HYK) and (2) the total cost per case of HYK when accounting for costs related to HYK-attributed diseases. Data from current literature was used to model the incidence and risks of HYK (defined as a blood $\beta$-hydroxybutyrate concentration $\geq 1.2 \mathrm{mmol} / \mathrm{L}$ ), displaced abomasa (DA), metritis, disease associations, milk production, culling, and reproductive outcomes. The component cost of HYK was estimated based on 1,000 calvings per year; the incidence of HYK in primiparous and multiparous animals; the percent of animals receiving clinical treatment; the direct costs of diagnostics, therapeutics, labor, and death loss; and the indirect costs of future milk production losses, future culling losses, and reproduction losses. Costs attributable to DA and metritis were estimated based on the incidence of each disease in the first 30 DIM; the number of cases of each disease attributable to HYK; the direct costs of diagnostics, therapeutics, discarded milk during treatment and the withdrawal period, veterinary service (DA only), and death loss; and the indirect costs of future milk production losses, future culling losses, and reproduction losses. The component cost per case of HYK was estimated at $\$ 134$ and $\$ 111$ for primiparous and multiparous animals, respectively; the average component cost per case of HYK was estimated to be $\$ 117$. Thirty-four percent of the component cost of HYK was due to future reproductive losses, $26 \%$ to death loss, $26 \%$ to future milk production losses, $8 \%$ to future culling losses, $3 \%$ to therapeutics, $2 \%$ to labor, and $1 \%$ to diagnostics. The total cost per case of HYK was estimated at $\$ 375$ and $\$ 256$ for primiparous and multiparous animals, respectively; the average total cost per case of HYK was $\$ 289$. Forty-one percent of the total cost of HYK was due to the component cost
\end{abstract}

Received August 12, 2014.

Accepted December 3, 2014.

${ }^{1}$ Corresponding author: moverton@elanco.com of HYK, $33 \%$ to costs attributable to metritis, and $26 \%$ to costs attributable to DA. The high total cost of HYK at reported incidences of 40 to $60 \%$ highlights the importance of appropriate transition cow nutrition and management to decrease the effect of HYK.

Key words: dairy cow, hyperketonemia, component cost, total cost

\section{INTRODUCTION}

Negative energy balance occurs in early lactation dairy cattle when energy expenditure due to milk production exceeds that available via feed intake (Bauman and Currie, 1980; Grummer, 1995; Herdt, 2000). Production of NEFA and ketone bodies (e.g., BHBA), which act as alternate fuel sources, are normal sequelae to negative energy balance adaptation, and thus certain circulating concentrations of these negative energy metabolites in the blood are normal during this stage of lactation. However, excessive production of NEFA and BHBA are indicative of a poor adaptive response to negative energy balance, and numerous studies have reported on the detrimental effects of elevated NEFA and BHBA on early lactation immune function (Hammon et al., 2006; Contreras et al., 2010; Ster et al., 2012), milk production (Duffield et al., 2009; Ospina et al., 2010a; Chapinal et al., 2012), and subsequent negative health events (Ospina et al., 2010b; Chapinal et al., 2011; Seifi et al., 2011).

Due to ease of measurement and quantification, the negative effects of elevated blood BHBA concentrations and resulting diagnosis of hyperketonemia (HYK; BHBA $\geq 1.2 \mathrm{mmol} / \mathrm{L}$ ) are better documented than those for elevated blood NEFA concentrations (McArt et al., 2013; Ospina et al., 2013). Although the incidence of HYK in early lactation has been reported to range from 40 to $60 \%$ (Duffield et al., 1998; McArt et al., 2012), there are few published reports on the economic effect of HYK. Although not the main objective of their studies, Duffield (2000) and Geishauser et al. (2001) estimated the cost per case of HYK between Canadian $\$ 50$ and $\$ 100$ and US\$78, respectively. In general, one reason for the variation in disease cost estimates is the 
inclusion of different components or inputs in each estimate, which can lead to an over- or underestimation of the cost of disease.

Although the cost of HYK as ascribed to direct consequences of the effect of this condition on milk production, treatment, and culling (reported here as the component cost) is important, so is the cost of other diseases attributed to HYK (i.e., the increase in disease risk associated with HYK). The total cost of HYK, the sum of the component cost and additional disease-attributed costs, can then be used to estimate the economic effect of HYK and the financial benefits behind improved management and prevention of HYK. However, summation of the total cost of multiple diseases can overestimate the economic effect when multiple disease events are considered. For example, if an early lactation dairy cow develops HYK, metritis, and a displaced abomasum (DA), summation of the total costs of HYK, metritis, and a DA might involve double counting of certain costs (e.g., accounting for DA costs on a DA-disease basis as well as attributing costs associated with DA development associated with HYK). This leads to an overestimation of the economic health consequences of multiple diseases in a cow. To prevent this double counting, summation of the individual component costs of HYK, metritis, and DA allows for a more accurate economic estimate of the economic consequences of multiple disease occurrences. The objective of the current study was to use a deterministic model to estimate the costs associated with (1) the component cost per case of HYK and (2) the total cost per case of HYK when accounting for the costs related to HYK-attributable DA and metritis cases.

\section{MATERIALS AND METHODS}

\section{Model Inputs}

Model input variables and values used to estimate the component cost of HYK are presented in Table 1. The marginal milk value was calculated using a feed price per unit of DM (lactating cow TMR) of $\$ 0.33$ per $\mathrm{kg}$ (St-Pierre and Cobanov, 2014; www.sesamesoft.com), an energy density of feed $\left(\mathrm{NE}_{\mathrm{L}}\right.$ per unit of feed) of 1.72 per $\mathrm{kg}$ (NRC, 2001), megacalories of $\mathrm{NE}_{\mathrm{L}}$ required per unit of marginal milk of 0.70 per $\mathrm{kg}$ (NRC, 2001), and a milk price of $\$ 0.53$ per kg (USDA National Agricultural Statistics Service, 2014). The total cost of HYK was estimated using the model inputs for the component cost of HYK as well as the DA (Table 2) and metritis (Table 3) costs attributable to HYK. Mastitis was not used in calculating costs attributable to HYK, as current literature does not provide robust estimates of the magnitude of the effect of its association with HYK; the costs associated with retained placenta are represented within the cost of metritis. Risk ratios (RR) used to calculate input values associated with culling, death, DA and metritis development, pregnancy to first service, and ovarian dysfunction in Table 1, Table 2, and Table 3 are as follows: herd removal rate in the first 30 DIM $=$ $6.0 \%$ for primiparous animals and $6.3 \%$ for multiparous animals; percent of herd removals in the first 30 DIM due to death $=45 \%$ (McArt et al., 2012; J. McArt, D. Nydam, and G. Oetzel, University of Wisconsin, Madsion; unpublished data); RR of culling in animals with HYK in the first 30 DIM versus non-HYK animals = 1.8 (McArt et al., 2012; Roberts et al., 2012); RR of culling in animals developing HYK in the first week of lactation versus the second week of lactation $=4.5$ (McArt et al., 2012); RR of DA development in animals with HYK versus non-HYK animals $=8.0$ (LeBlanc et al., 2005; Duffield et al., 2009; McArt et al., 2012); RR of metritis development in animals with HYK versus non-HYK animals = 3.3 (Duffield et al., 2009; Ospina et al., 2010b); RR of ovarian dysfunction in animals with HYK versus non-HYK animals $=5$ (Dohoo and Martin, 1984; Hooijer et al., 2001; López-Gatius, 2003); and RR of pregnancy to first service in animals with HYK versus non-HYK animals $=0.8$ (Walsh et al., 2007). Items listed in tables concerning medication use, route of administration, dosage, and number of treatments are not treatment recommendations but meant to reflect commonly used and literature-supported treatment protocols used on dairies.

\section{Model Development}

A deterministic partial budget model to estimate the component and total costs of HYK was developed using Excel (Microsoft, Redmond, WA). The component cost of HYK refers to the sum of costs associated with HYK alone, whereas the total cost of HYK refers to the sum of the component cost and the costs associated with diseases attributable to HYK (i.e., DA and metritis). The component cost of HYK was estimated based on 1,000 calvings per year; the incidence of HYK in primiparous and multiparous animals (BHBA $\geq 1.2 \mathrm{mmol} / \mathrm{L}$ ); the percent of animals receiving clinical treatment; the direct costs of diagnostics (the cost for confirmation and retesting of cases across all HYK animals), therapeutics, labor, and death loss; and the indirect costs of future milk production losses, future culling losses, and reproduction losses. The total cost of HYK was estimated by summing the component cost of HYK plus costs attributable to DA and metritis, which were estimated based on the incidence of each disease in the first 30 DIM; the number of cases of each disease attributable to HYK; the direct costs of diagnostics, 
Table 1. Deterministic model inputs to estimate the component cost per case of hyperketonemia (HYK) in early lactation dairy cattle

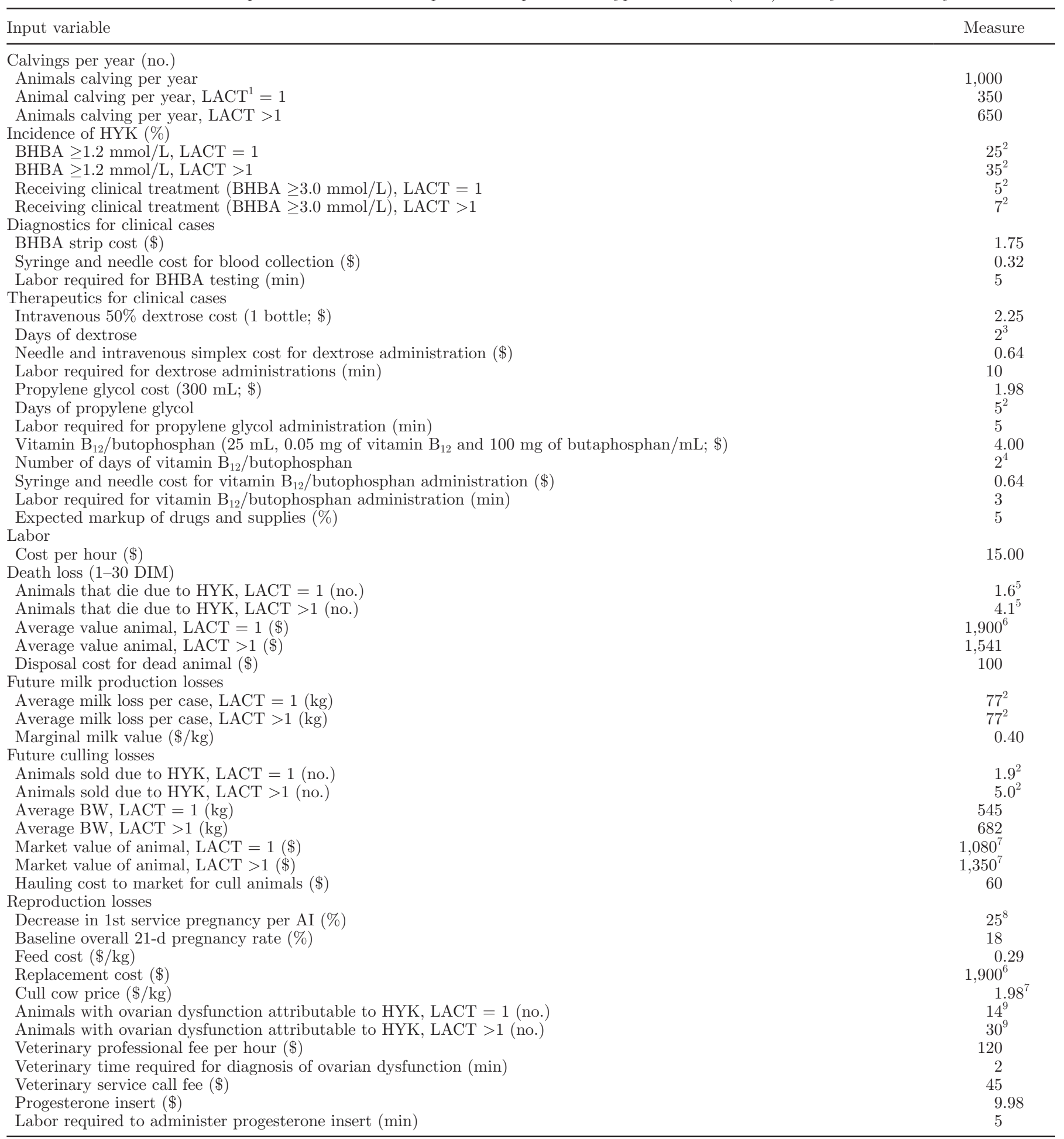

${ }^{1} \mathrm{LACT}=$ lactation.

${ }^{2}$ McArt et al. (2012).

${ }^{3}$ Wagner and Schimek (2010); Gordon et al. (2013).

${ }^{4}$ Rollin et al. (2010); Gordon et al. (2012).

${ }^{5}$ McArt et al. (2012); Roberts et al. (2012).

${ }^{6}$ Replacement heifer prices calculated from USDA, Agriculture Marketing Service (2014).

${ }^{7}$ Cull cow prices calculated from USDA, Agriculture Marketing Service (2014).

${ }^{8}$ Walsh et al. (2007).

${ }^{9}$ Dohoo and Martin (1984); Ijaz et al. (1987); Hooijer et al. (2001); López-Gatius (2003). 
Table 2. Deterministic model inputs to estimate the displaced abomasum (DA) costs attributable to hyperketonemia (HYK) in early lactation dairy cattle

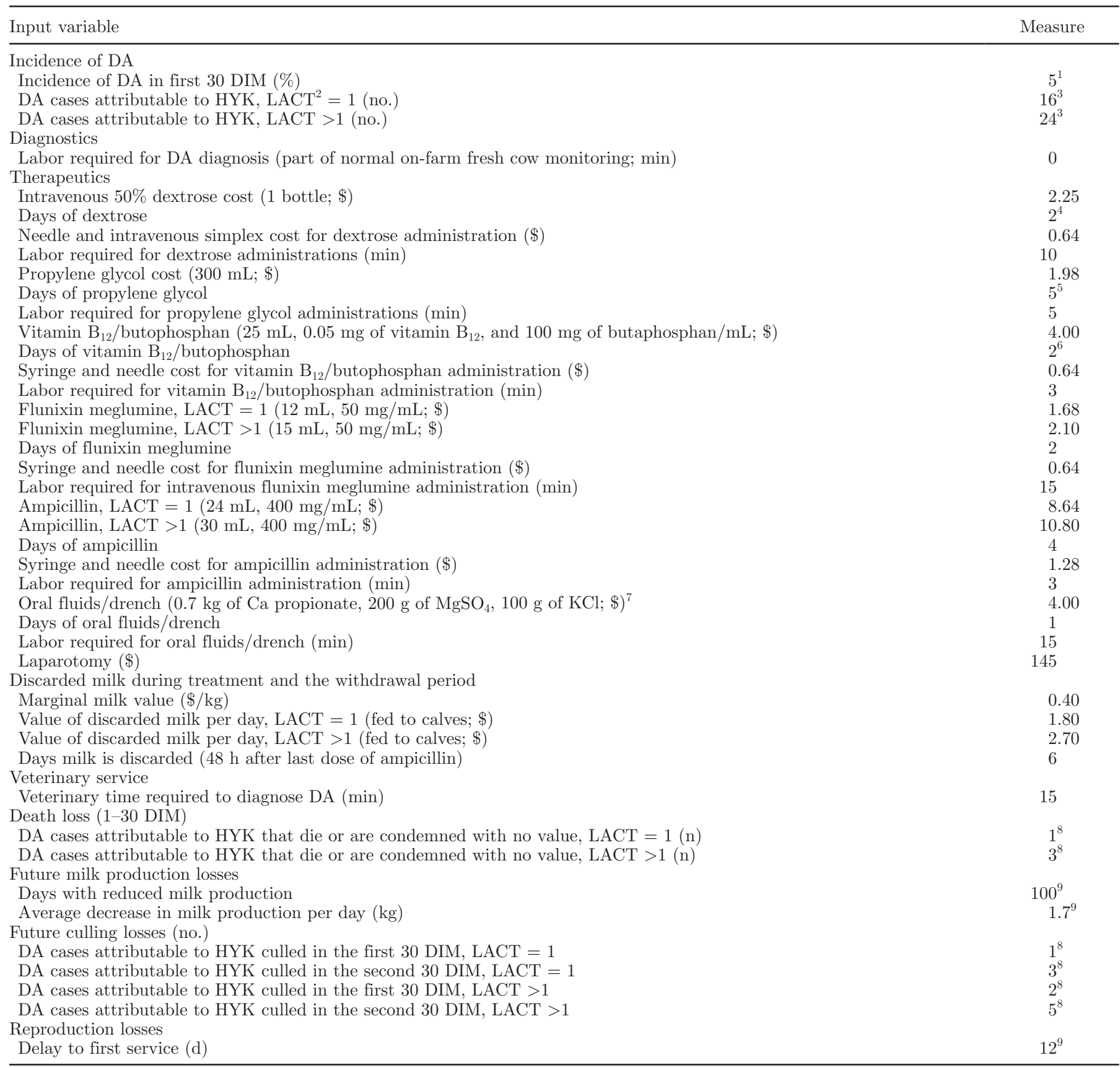

${ }^{1}$ Shaver (1997).

${ }^{2} \mathrm{LACT}=$ lactation.

${ }^{3}$ LeBlanc et al. (2005); Duffield et al. (2009); McArt et al. (2012).

${ }^{4}$ Wagner and Schimek (2010); Gordon et al. (2013).

${ }^{5} \mathrm{McArt}$ et al. (2012).

${ }^{6}$ Rollin et al. (2010); Gordon et al. (2012).

${ }^{7}$ Stokes and Goff (2001).

${ }^{8}$ Sterner et al. (2008).

${ }^{9}$ Raizman and Santos (2002). 
Table 3. Deterministic model inputs to estimate the metritis costs attributable to hyperketonemia (HYK) in early lactation dairy cattle

\begin{tabular}{|c|c|}
\hline Input variable & Measure \\
\hline \multicolumn{2}{|l|}{ Incidence of metritis } \\
\hline Incidence of metritis in first $30 \mathrm{DIM}, \mathrm{LACT}^{1}=1(\%)$ & 20 \\
\hline Incidence of metritis in first $30 \mathrm{DIM}, \mathrm{LACT}>1(\%)$ & 10 \\
\hline Incidence of toxic metritis in first 30 DIM (\%) & 5 \\
\hline Cases of metritis attributable to HYK, LACT $=1$ (no.) & $32^{2}$ \\
\hline Cases of metritis attributable to HYK, LACT >1 (no.) & $43^{2}$ \\
\hline \multicolumn{2}{|l|}{ Diagnostic } \\
\hline Labor required for metritis diagnosis (part of normal on-farm fresh cow monitoring: min) & 0 \\
\hline \multicolumn{2}{|l|}{ Therapeutics for metritis } \\
\hline Ceftiofur crystalline free acid, LACT $=1(18 \mathrm{~mL}, 200 \mathrm{mg} / \mathrm{mL} ; \$)$ & 30.24 \\
\hline Ceftiofur crystalline free acid, LACT >1 (22.5 mL, $200 \mathrm{mg} / \mathrm{mL} ; \$)$ & 37.80 \\
\hline Ceftiofur crystalline free acid treatments (no.) & 2 \\
\hline Syringe and needle cost for ceftiofur crystalline free acid administration $(\$)$ & 0.64 \\
\hline Labor required for ceftiofur crystalline free acid administration (min) & 15 \\
\hline \multicolumn{2}{|l|}{ Therapeutics for toxic metritis } \\
\hline Flunixin meglumine, LACT $=1(12 \mathrm{~mL}, 50 \mathrm{mg} / \mathrm{mL} ; \$)$ & 1.68 \\
\hline Flunixin meglumine, LACT >1 (15 mL, $50 \mathrm{mg} / \mathrm{mL} ; \$)$ & 2.10 \\
\hline Days of flunixin meglumine & 2 \\
\hline Syringe and needle cost for flunixin meglumine administration $(\$)$ & 0.64 \\
\hline Labor required for intravenous flunixin meglumine administration (min) & 15 \\
\hline Ampicillin, LACT $=1(24 \mathrm{~mL}, 400 \mathrm{mg} / \mathrm{mL} ; \$)$ & 8.64 \\
\hline Ampicillin, LACT >1 (30 mL, $400 \mathrm{mg} / \mathrm{mL} ; \$)$ & 10.80 \\
\hline Days of ampicillin & 4 \\
\hline Syringe and needle cost for ampicillin administration $(\$)$ & 1.28 \\
\hline Labor required for ampicillin administration (min) & 3 \\
\hline Calcium bolus ( $43 \mathrm{~g}$ of calcium; $\$$ ) & 5.58 \\
\hline Number of calcium bolus treatments & $2^{3}$ \\
\hline Labor required for calcium bolus (min) & 5 \\
\hline Intravenous hypertonic saline $(2 \mathrm{~L}, 7-7.5 \%$ solution; $\$)$ & 7.88 \\
\hline Doses of intravenous hypertonic saline (no.) & 1 \\
\hline Syringe and needle cost for administration of intravenous hypertonic saline $(\$)$ & 0.32 \\
\hline Labor required for intravenous hypertonic saline $(\min )$ & 10 \\
\hline Oral fluids/drench ${ }^{4}\left(0.7 \mathrm{~kg}\right.$ of Ca propionate, $200 \mathrm{~g}$ of $\mathrm{MgSO}_{4}, 100 \mathrm{~g}$ of $\left.\mathrm{KCl} ; \$\right)$ & 4.00 \\
\hline Days of oral fluids/drench & 1 \\
\hline Labor required for oral fluids/drench (min) & 15 \\
\hline \multicolumn{2}{|l|}{ Discarded milk during treatment and the withdrawal period } \\
\hline Value of discarded milk per day, LACT $=1$ (fed to calves; $\$$ ) & 1.80 \\
\hline Value of discarded milk per day, LACT $>1$ (fed to calves; $\$$ ) & 2.70 \\
\hline Days milk is discarded ( $48 \mathrm{~h}$ after last dose of ampicillin) & 6 \\
\hline \multicolumn{2}{|l|}{ Death loss (1-30 DIM) due to toxic metritis (no.) } \\
\hline Metritis cases attributable to HYK that die, LACT $=1$ & $1^{5}$ \\
\hline Metritis cases attributable to HYK that die, LACT >1 & $2^{5}$ \\
\hline \multicolumn{2}{|l|}{ Future milk production losses $(\mathrm{kg})$} \\
\hline Average decrease in milk production from 1 to 30 DIM & $6.9^{5}$ \\
\hline Average decrease in milk production from 31 to 60 DIM & $4.1^{5}$ \\
\hline Average decrease in milk production past 60 DIM & $2.7^{5}$ \\
\hline \multicolumn{2}{|l|}{ Future culling losses (no.) } \\
\hline Metritis cases attributable to HYK that are culled, LACT $=1$ & $2^{5}$ \\
\hline Metritis cases attributable to HYK that are culled, LACT $>1$ & $2^{5}$ \\
\hline \multicolumn{2}{|l|}{ Reproduction losses (\%) } \\
\hline Decrease in 21 -d pregnancy rate (e.g., 18 to $14 \%$ ) & $4^{5}$ \\
\hline \multicolumn{2}{|l|}{${ }^{1} \mathrm{LACT}=$ lactation } \\
\hline \multicolumn{2}{|l|}{${ }^{2}$ Duffield et al. (2009); Ospina et al. (2010b). } \\
\hline \multicolumn{2}{|l|}{${ }^{3}$ Oetzel and Miller (2012). } \\
\hline \multicolumn{2}{|l|}{${ }^{4}$ Stokes and Goff (2001). } \\
\hline${ }^{5}$ Overton and Fetrow (2008). & \\
\hline
\end{tabular}

therapeutics, discarded milk during treatment and the withdrawal period (modeled based on feeding of waste milk to calves), veterinary service (DA only), and death loss; and the indirect costs of future milk production loses, future culling losses, and reproduction losses. In total, $88 \%$ of DA cases and $70 \%$ of metritis cases were attributed to HYK. These percentages were calculated using the underlying RR of DA and metritis development in HYK animals listed previously, an average HYK incidence across parities of $32 \%$, a DA incidence of $5 \%$, and an average metritis incidence across parities of $18.5 \%$. A 2 by 2 table used to calculate the per- 
Table 4. Percentage of displaced abomasa (DA) cases attributable to hyperketonemia in early lactation dairy cattle ${ }^{1}$

\begin{tabular}{lccr}
\hline Item $(\%)$ & DA & No DA & Total \\
\hline Hyperketonemia & 40 & 280 & 320 \\
No hyperketonemia & 10 & 670 & 680 \\
Total & 50 & 950 & 1,000 \\
\hline
\end{tabular}

${ }^{1}$ Use of this information to calculate the attributable risk resulted in $88 \%$ of DA cases in hyperketonemic cows being attributed to hyperketonemia.

centage of DA cases attributable to HYK (Table 4) was developed using the previously mentioned values. The risk of DA development in an HYK animal (Risk $\mathrm{DA}_{\mathrm{HYK}}$ ) was calculated from Table 4 to be $12.5 \%$; the risk of DA development in a non-HYK animal (Risk $\mathrm{DA}_{\mathrm{N}}$ ) was calculated to be $1.5 \%$. The attributable risk of DA to HYK (the percent of disease in the exposed population attributable to exposure) was then calculated as

$$
\left(\text { Risk } \mathrm{DA}_{\mathrm{HYK}}-\text { Risk } \mathrm{DA}_{\mathrm{N}}\right) /\left(\text { Risk } \mathrm{DA}_{\mathrm{HYK}}\right)=0.88 \text {. }
$$

Thus, $88 \%$ of DA cases were attributed to HYK. The percentage of metritis cases attributable to HYK were calculated in the same manner using Table 5, which resulted in a risk of metritis development in an HYK animal (Risk $\mathrm{MET}_{\mathrm{HYK}}$ ) of $35.3 \%$ and a risk of metritis development in a non-HYK animal (Risk $\mathrm{MET}_{\mathrm{N}}$ ) of $10.6 \%$. The attributable risk of metritis to HYK was then calculated as

$\left(\right.$ Risk $\mathrm{MET}_{\mathrm{HYK}}-$ Risk $\left.\mathrm{MET}_{\mathrm{N}}\right) /\left(\right.$ Risk $\left.\mathrm{MET}_{\mathrm{HYK}}\right)=0.70$.

Metritis and DA costs attributable to HYK were then calculated by multiplying each cost by the incidence of the disease in HYK animals and the percentage of disease cases attributed to HYK.

To account for variation in HYK, DA, and metritis incidence across farms, the average total cost per case of HYK was modeled at 3 different incidences for each disease; each input variable was adjusted singularly with all others remaining constant to assess the effect of a $50 \%$ reduction and a $50 \%$ increase in the incidence

Table 5. Percentage of metritis (MET) cases attributable to hyperketonemia in early lactation dairy cattle ${ }^{1}$

\begin{tabular}{lrcr}
\hline Item $(\%)$ & MET & No MET & Total \\
\hline Hyperketonemia & 113 & 207 & 320 \\
No hyperketonemia & 72 & 608 & 680 \\
Total & 185 & 815 & 1,000 \\
\hline
\end{tabular}

${ }^{1}$ Use of this information to calculate the attributable risk resulted in $70 \%$ of metritis cases in hyperketonemic cows being attributed to hyperketonemia. of each disease. As current market values for the price of milk, cost of feed, and market cow price are high compared with historic values, each of these variables was singularly adjusted in the model with all other variables held constant to assess the effect of a 20 and $40 \%$ reduction in price on the average total cost per case of HYK. Graphs to illustrate the effect of variations in HYK, DA, and metritis incidence and price of milk, cost of feed, and market cow price on the average total cost per case of HYK were developed using Excel (Microsoft).

\section{RESULTS AND DISCUSSION}

Deterministic modeling was conducted to estimate the component and total costs per case of HYK. Models were developed with the assumption that $35 \%$ of calvings were from primiparous cows. Twenty-five percent of primiparous cows and $35 \%$ of multiparous cows were assumed to develop HYK (BHBA $\geq 1.2 \mathrm{mmol} / \mathrm{L}$ ), and $20 \%$ of HYK-positive animals were assumed to develop clinical ketosis (BHBA $\geq 3.0 \mathrm{mmol} / \mathrm{L}$ ).

The component cost per case of HYK was estimated at $\$ 134$ and $\$ 111$ for primiparous and multiparous animals, respectively; the average component cost per case of HYK was estimated to be $\$ 117$ (Table 6). As the average component cost per case was modeled using an assumption of $35 \%$ primiparous calvings, a herd with a higher percentage of primiparous calvings would have an increased component cost per case. The difference in cost between primiparous versus multiparous cows is primarily due to a higher animal value for first-lactation animals when considering the direct cost of death loss as well as the increase in lost value to the herd when considering the indirect cost of future culling losses. As the partial costs of death loss and future culling losses account for $34 \%$ of the component cost of HYK in an average case (Figure 1), herds with a higher proportion of first-lactation animals will incur larger total longterm financial repercussions than herds with more multiparous animals. This model also highlights the minor contribution of labor, diagnostics, and therapeutics, which account for only $6 \%$ of the component cost per case of HYK. As an example, this study provides information based on commonly used on-farm HYK treatments, and some herds may use more or less expensive treatment protocols. If no therapeutic treatments were given for HYK cases in a herd, the average component cost per case would only decrease from $\$ 117$ to $\$ 114$.

The component costs of DA and metritis necessary to calculate the costs attributable to HYK are presented in Table 7 and 8, respectively, with an average component cost of $\$ 707$ per DA case and $\$ 396$ per case of metritis. These costs were used to calculate the disease 
Table 6. Estimated component cost per case of hyperketonemia (blood BHBA $\geq 1.2 \mathrm{mmol} / \mathrm{L}$ ) in early lactation dairy cattle (totals may differ from sum of costs due to rounding)

\begin{tabular}{lccc}
\hline Item $(\$)$ & $\begin{array}{c}\text { Cost per case, } \\
\text { LACT }^{1}=1\end{array}$ & $\begin{array}{c}\text { Cost per case, } \\
\text { LACT }>1\end{array}$ & $\begin{array}{c}\text { Average cost } \\
\text { per case }\end{array}$ \\
\hline $\begin{array}{l}\text { Direct cost of hyperketonemia } \\
\text { Diagnostic }\end{array}$ & $(1)^{2}$ & $(1)$ & $(1)$ \\
Therapeutic & $(3)$ & $(3)$ & $(3)$ \\
Discarded milk & 0 & 0 & 0 \\
Veterinary service & 0 & 0 & $(2)$ \\
Labor & $(2)$ & $(29)$ & $(31)$ \\
Death loss & $(36)$ & $(30)$ & $(30)$ \\
Indirect cost of hyperketonemia & $(30)$ & $(39)$ & $(9)$ \\
Future milk production losses & $(19)$ & $(111)$ & $(40)$ \\
Future culling losses & $(41)$ & & \\
Reproduction losses & $(134)$ & & \\
Total & & &
\end{tabular}

specific costs attributable to HYK used in Table 9. For example, as the component cost of a DA was calculated to be $\$ 707$, with an incidence of DA in HYK animals of $12.5 \%$ and $88 \%$ of DA cases attributed to HYK, the average DA cost attributed to HYK was estimated to be $\$ 76$. Similar to the component cost of HYK, firstlactation animals have higher DA costs attributable to HYK primarily due to death loss and future culling losses. Additionally, primiparous cows are at a higher

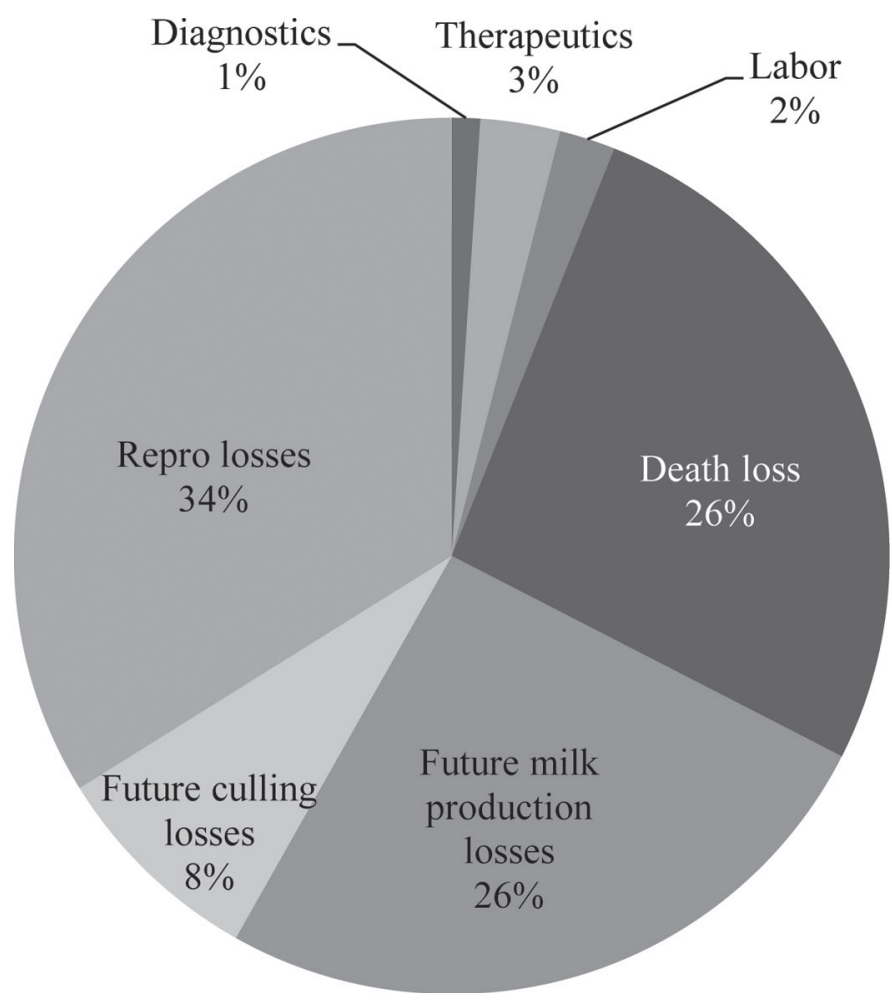

Figure 1. Pie chart showing the percent contribution of each direct and indirect cost for the average case component cost of hyperketonemia. Repro $=$ reproduction . risk for DA due to HYK than multiparous cows (McArt et al., 2012; J. McArt, D. Nydam, and G. Oetzel, University of Wisconsin, Madsion; unpublished data); thus the cost for therapeutics, discarded milk, veterinary service, labor, and future milk production and reproduction losses are slightly higher than for multiparous animals. The total cost of metritis attributable to HYK was almost twice as much for primiparous than multiparous cows due mainly to cost of therapeutics as well as future milk production, culling, and reproduction losses. As first-lactation animals are at a higher risk for metritis, they have higher treatment costs and costs due to the metritis-associated complications of reduced milk production, increased culling, and poor reproduction, on average, because of a higher incidence of metritis in the population.

Previously reported estimates of the cost per DA case stem from work described by Guard (2008). An estimate of $\$ 498$ per DA case was calculated when the percent death per case, percent culled per case, milk not produced, milk discarded, extra days open, farm labor, veterinary service, and drug costs were taken into account (C. Guard, Cornell University, Ithaca, NY; personal communication, 2012). The main cost discrepancy between these 2 calculations result from a lower cost per dead cow and a lower cost associated with veterinary service and drug costs used in the Guard (2008) estimation. As it is unclear where input values were attained, further investigation is limited. The cost per case of metritis has previously been described by Bartlett et al. (1986) as $\$ 106$ per case ( $\$ 230$ when adjusted for inflation; US Department of Labor, 2014). However, no economic effect from milk loss was included in the calculation and a low overall culling risk was used. These differences may explain the approximately $\$ 150$ difference in estimations of the component cost per case of metritis. 
Table 7. Estimated component cost per case of displaced abomasum (totals may differ from sum of costs due to rounding)

\begin{tabular}{lccc}
\hline Item $(\$)$ & $\begin{array}{c}\text { Cost per case, } \\
\text { LACT }^{1}=1\end{array}$ & $\begin{array}{c}\text { Cost per case, } \\
\text { LACT }>1\end{array}$ & $\begin{array}{c}\text { Average cost } \\
\text { per case }\end{array}$ \\
\hline $\begin{array}{l}\text { Direct cost of displaced abomasum } \\
\text { Diagnostic }\end{array}$ & 0 & 0 & 0 \\
Therapeutic & $(212)^{2}$ & $(222)$ & $(219)$ \\
Discarded milk & $(11)$ & $(16)$ & $(14)$ \\
Veterinary service & $(75)$ & $(75)$ & $(45)$ \\
Labor & $(160)$ & $(130)$ & $(141)$ \\
Death loss & $(56)$ & $(56)$ & $(136)$ \\
Indirect cost of displaced abomasum & $(210)$ & $(29)$ & $(29)$ \\
Future milk production losses & $(29)$ & $(661)$ & $(707)$ \\
Future culling losses & $(792)$ & & \\
Reproduction losses & & &
\end{tabular}

The time sequence regarding diagnosis of HYK and subsequent DA development has been well reported (Geishauser et al., 1997; LeBlanc et al., 2005; Duffield et al., 2009); however, debate exists over the relationship between HYK and metritis, as the 2 diseases often occur at similar time points in early lactation. In both Duffield et al. (2009) and Ospina et al. (2010b), where the investigators were careful to only attribute metritis that occurred after HYK diagnosis, an increase in the odds or risk of subsequent metritis diagnosis was reported; however, a study by Chapinal et al. (2011) found no association between these 2 diseases. Although it is apparent that not all cases of metritis are related to HYK, attributing a certain proportion of metritis cases to HYK is within reason. The attribution of metritis and DA cases to HYK does not directly infer a cause and effect relationship; more likely a common preceding physiologic issue, for example a reduction in prepartum DMI (Huzzey et al., 2007; Goldhawk et al., 2009), is contributing to the development of these diseases. The presence of HYK merely explains the occurrence of a large proportion of the attributed diseases.

The total cost per case of HYK was estimated at $\$ 375$ and $\$ 256$ for primiparous and multiparous animals, respectively; the average total cost per case of HYK was $\$ 289$ (Table 8). A pie chart showing the percent contribution to the total cost per case of HYK of the component cost of HYK and the DA and metritis costs attributable to HYK is presented in Figure 2. Two other studies have estimated the cost of HYK, although less extensively than the reported modeling exercise. Duffield (2000) approximated the cost per case of HYK (BHBA $\geq 1.4 \mathrm{mmol} / \mathrm{L}$ ) to be Canadian $\$ 50$ to $\$ 100$ when accounting for the treatment, production, and culling costs associated with DA, clinical ketosis, and multiple illness (an animal having more than 1 of retained placenta, milk fever, metritis, endometritis, mastitis, ketosis, DA, digestive, lameness, respiratory, or other disease) attributed to cows with HYK. Geishauser et al. (2001) calculated the cost per

Table 8. Estimated component cost per case of metritis (totals may differ from sum of costs due to rounding)

\begin{tabular}{lccc}
\hline Item $(\$)$ & $\begin{array}{c}\text { Cost per case, } \\
\text { LACT }^{1}=1\end{array}$ & $\begin{array}{c}\text { Cost per case, } \\
\text { LACT }>1\end{array}$ & $\begin{array}{c}\text { Average cost } \\
\text { per case }\end{array}$ \\
\hline $\begin{array}{l}\text { Direct cost of metritis } \\
\text { Diagnostic }\end{array}$ & 0 & 0 & 0 \\
Therapeutic & $(67)^{2}$ & $(83)$ & $(75)$ \\
Discarded milk & $(3)$ & $(6)$ & $(5)$ \\
Veterinary service & 0 & $(10)$ & $(12)$ \\
Labor & $(20)$ & $(109)$ & $(28)$ \\
Death loss & $(109)$ & $(10)$ & $(109)$ \\
Indirect cost of metritis & $(28)$ & $(150)$ & $(18)$ \\
Future milk production losses & $(150)$ & & $(396)$ \\
Future culling losses & $(386)$ & & \\
Reproduction losses & & &
\end{tabular}


Table 9. Estimated total cost per case of hyperketonemia (blood BHBA $\geq 1.2 \mathrm{mmol} / \mathrm{L}$ ) in early lactation dairy cattle (totals may differ from sum of costs due to rounding)

\begin{tabular}{|c|c|c|c|}
\hline Item ( $\$$, unless otherwise noted) & $\begin{array}{l}\text { Cost per case, } \\
\text { LACT }^{1}=1\end{array}$ & $\begin{array}{c}\text { Cost per case, } \\
\text { LACT }>1\end{array}$ & $\begin{array}{c}\text { Average cost } \\
\text { per case }\end{array}$ \\
\hline \multicolumn{4}{|l|}{ Component cost of hyperketonemia } \\
\hline \multicolumn{4}{|l|}{ Direct cost of hyperketonemia } \\
\hline Diagnostic & $(1)^{2}$ & (1) & (1) \\
\hline Therapeutic & (3) & (3) & (3) \\
\hline Discarded milk & 0 & 0 & 0 \\
\hline Veterinary service & 0 & 0 & 0 \\
\hline Labor & (2) & $(2)$ & $(2)$ \\
\hline Death loss & $(36)$ & (29) & (31) \\
\hline \multicolumn{4}{|l|}{ Indirect cost of hyperketonemia } \\
\hline Future milk production losses & $(30)$ & $(30)$ & $(30)$ \\
\hline Future culling losses & (19) & $(5)$ & (9) \\
\hline Reproduction losses & $(41)$ & (39) & $(40)$ \\
\hline Total & $(134)$ & $(111)$ & $(117)$ \\
\hline Total cost per case $(\%)$ & 36 & 44 & 41 \\
\hline \multicolumn{4}{|l|}{$\mathrm{DA}^{3}$ costs attributable to hyperketonemia } \\
\hline \multicolumn{4}{|l|}{ Direct cost of DA } \\
\hline Diagnostic & 0 & 0 & 0 \\
\hline Therapeutic & $(27)$ & $(23)$ & $(24)$ \\
\hline Discarded milk & (1) & $(2)$ & $(2)$ \\
\hline Veterinary service & $(10)$ & $(8)$ & $(8)$ \\
\hline Labor & $(5)$ & (4) & $(4)$ \\
\hline Death loss & $(20)$ & $(13)$ & $(15)$ \\
\hline \multicolumn{4}{|l|}{ Indirect cost of DA } \\
\hline Future milk production losses & $(7)$ & (6) & (6) \\
\hline Future culling losses & $(27)$ & (9) & (14) \\
\hline Reproduction losses & $(4)$ & (3) & (3) \\
\hline Total & $(101)$ & $(67)$ & $(76)$ \\
\hline Total cost per case $(\%)$ & 27 & 26 & 26 \\
\hline \multicolumn{4}{|c|}{ Metritis costs attributable to hyperketonemia } \\
\hline \multicolumn{4}{|c|}{ Direct cost of metritis } \\
\hline Diagnostic & 0 & 0 & 0 \\
\hline Therapeutic & $(24)$ & $(16)$ & $(18)$ \\
\hline Discarded milk & (1) & $(1)$ & (1) \\
\hline Veterinary service & 0 & 0 & 0 \\
\hline Labor & $(4)$ & $(2)$ & $(3)$ \\
\hline Death loss & (7) & (7) & (7) \\
\hline \multicolumn{4}{|l|}{ Indirect cost of metritis } \\
\hline Future milk production losses & $(40)$ & $(20)$ & $(26)$ \\
\hline Future culling losses & $(10)$ & $(2)$ & $(4)$ \\
\hline Reproduction losses & $(55)$ & $(29)$ & $(36)$ \\
\hline Total & $(141)$ & $(77)$ & $(95)$ \\
\hline Total cost per case $(\%)$ & 37 & 30 & 33 \\
\hline Total cost per case of hyperketonemia & $(375)$ & $(256)$ & $(289)$ \\
\hline
\end{tabular}

case of HYK (diagnosed based on a serum BHBA $\geq 1.4$ $\mathrm{mmol} / \mathrm{L}$ or milk acetoacetic acid $\geq 100 \mu \mathrm{mol})$ to be $\$ 78$ when accounting for milk losses extending for 2 wk postdiagnosis, a 2-wk extended calving-to-conception interval, and a 3 -fold increased risk of DA and clinical ketosis. The focus of these previous reports was not on the economics of HYK but rather to roughly estimate the losses resulting from HYK. In addition, research over the last decade has provided more quantifiable results regarding risk of disease occurrence as well as production and reproduction losses associated with HYK. For these reasons, the estimates of the cost of HYK from the previously mentioned reports may underes- timate the true cost per case. The reported total cost of $\$ 289$ per case of HYK may similarly be a conservative estimate, as mastitis and other infectious diseases were not included in the model even though HYK is associated with immune dysfunction (Suriyasathaporn et al., 2000; Zarrin et al., 2014a; Zarrin et al., 2014b). However, the lack of current literature linking HYK, immune function, and incidence of infectious diseases in early lactation precludes inclusion of these diseases in the model.

Herd disease incidence had an effect on the total cost per case of HYK (Figure 2). A 50\% increase or decrease in herd DA incidence changed the average total cost 

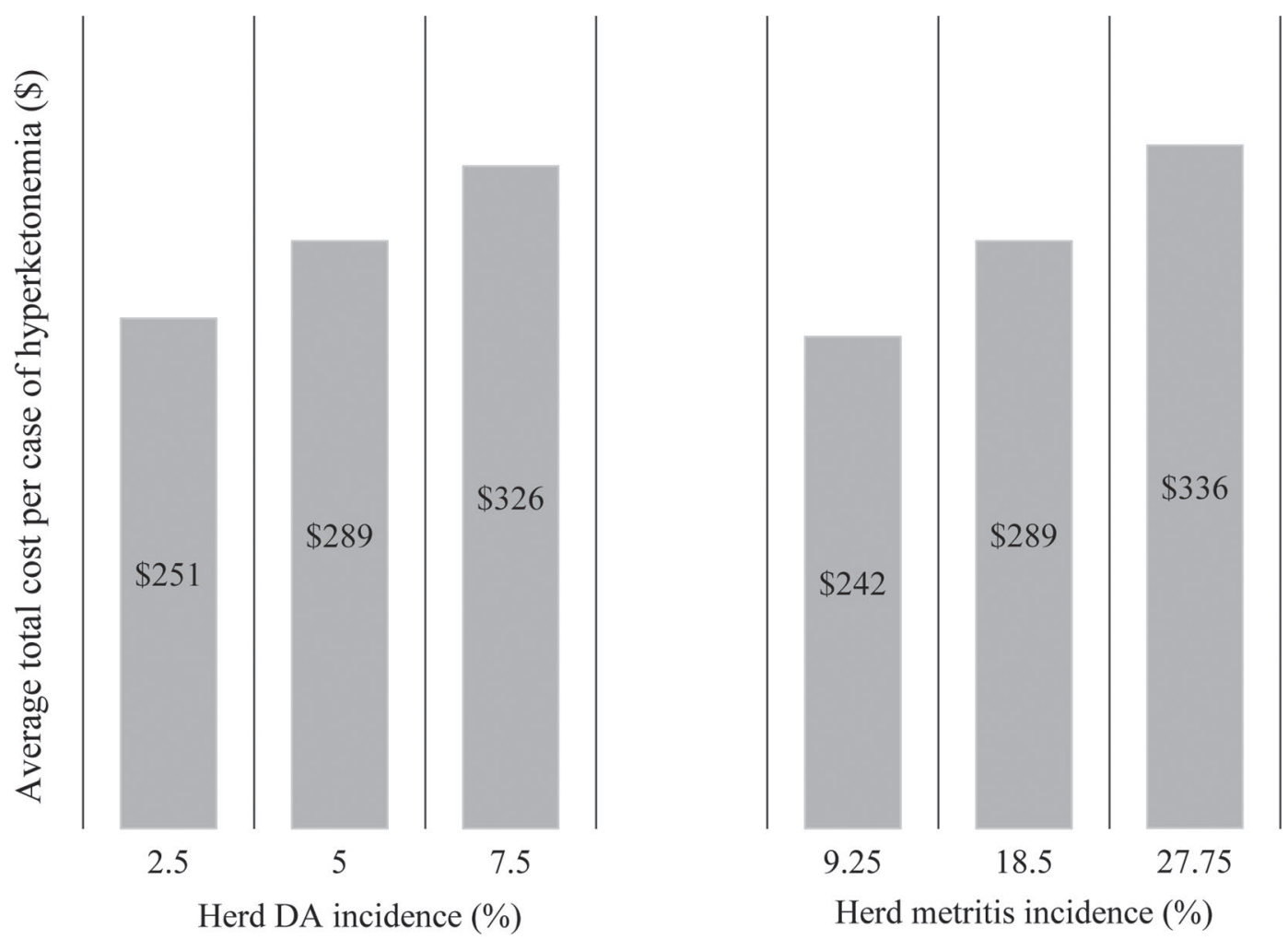

Figure 2. Bar chart showing the effect of herd disease incidence of displaced abomasum (DA) and metritis on the average total cost per case of hyperketonemia while all other inputs remain constant.

by $13 \%$ in each respective direction. Similarly, a $50 \%$ change in herd metritis incidence changed the average total cost by $16 \%$. As the costs attributable to metritis comprised a larger percentage of the total cost of HYK than those attributable to DA, it follows that the change in metritis incidence had a larger effect on the total cost of HYK than the change in DA incidence, assuming typical expected ranges of each disease in a herd. Although a $50 \%$ decrease in the DA or metritis incidence on a dairy would be significant at a herd disease level, the total cost per case of HYK still remains a large economic factor.

It is important to note that as herd incidence of HYK changed, the total cost per case of HYK remained unchanged. This is due to the fact that as HYK incidence increased, the number of DA and metritis cases proportionally increased, resulting in the same average cost per case of HYK. If this symbiosis was ignored and the incidence of HYK varied while the incidences of DA and metritis kept constant, then the average total cost per case of HYK at a herd incidence of 16, 32, and $48 \%$ was $\$ 357, \$ 289$, and $\$ 248$, respectively. In real herds from which the published RR used in the current model were derived, this dissociation did not occur; as HYK incidence increased or decreased, DA and metritis incidences responded accordingly.
Each $20 \%$ reduction in the price of milk, feed price, and market cow price resulted in a 13\% decrease, $5 \%$ increase, and $5 \%$ increase, respectively, in the average cost per case of HYK (Figure 3). Intuitively, as the price of milk decreased, the financial effect of future milk production losses decreased. Although a $40 \%$ reduction in the price of milk decreased the average total cost per case of HYK by over $25 \%$, the resulting estimate of $\$ 210$ per case is still a large financial burden considering the high incidence of HYK in many herds. Whereas an increase in the average cost per case of HYK was noted as the price of feed decreased (and thus the value of marginal milk increased) and similarly as the market cow price decreased (which increased the economic effect of future culling losses), this increase was not substantial and suggests these inputs do not have a large effect on the total cost of HYK.

Based on an estimated $\$ 289$ total cost per case of HYK for a herd with 1,000 calvings per year, a DA incidence of $5 \%$, a metritis incidence of approximately $20 \%$, and an HYK incidence of $32 \%$, the total cost of HYK approaches $\$ 90,000$ per year. As most HYK cases are subclinical in nature (McArt et al., 2013), the majority of these costs are unobserved. This reinforces the importance of proper nutritional and environmental management of dairy cows throughout the transition 

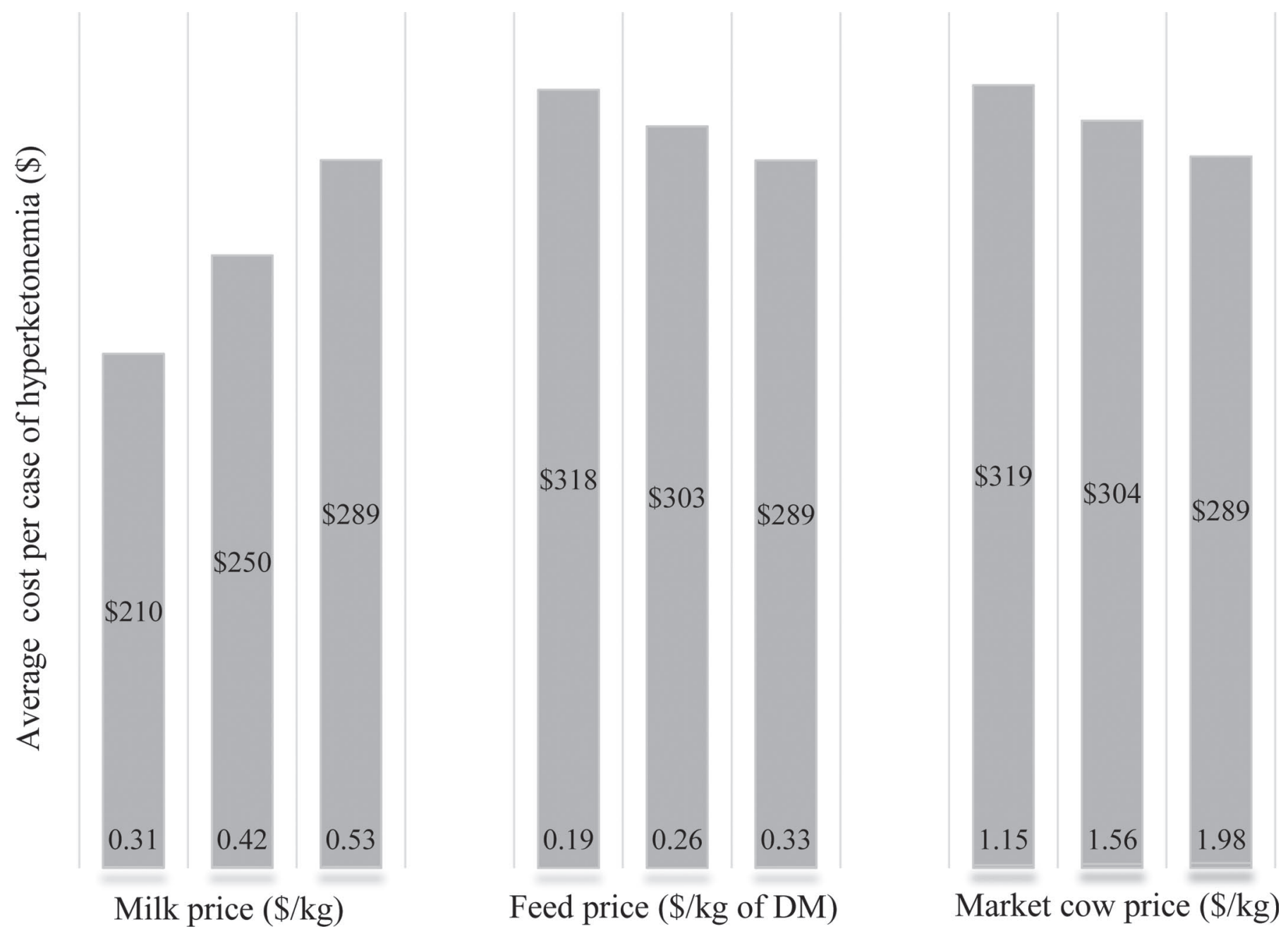

Figure 3. Bar chart showing the effect of variation in the price of milk, feed price, and market cow price on average total cost per case of hyperketonemia while all other inputs remain constant.

period to decrease the incidence of HYK and its subsequent negative health and production effects.

\section{CONCLUSIONS}

The average total cost per case of HYK across parity groups was estimated to be $\$ 289$ when accounting for the costs associated with HYK and subsequent attributable metritis and DA development. Financial losses were almost $50 \%$ higher in primiparous versus multiparous cows due to an increase in costs associated with death loss and future production, culling, and reproductive losses.

\section{REFERENCES}

Bartlett, P. C., J. H. Kirk, M. A. Wilke, J. B. Kaneene, and E. C. Mather. 1986. Metritis complex in Michigan Holstein-Friesian cat- tle: Incidence, descriptive epidemiology and estimated economic impact. Prev. Vet. Med. 4:235-248.

Bauman, D. E., and W. B. Currie. 1980. Partitioning of nutrients during pregnancy and lactation: A review of mechanisms involving homeostasis and homeorhesis. J. Dairy Sci. 63:1514-1529.

Chapinal, N., M. Carson, T. F. Duffield, M. Capel, S. Godden, M. Overton, J. E. Santos, and S. J. LeBlanc. 2011. The association of serum metabolites with clinical disease during the transition period. J. Dairy Sci. 94:4897-4903.

Chapinal, N., M. E. Carson, S. J. LeBlanc, K. E. Leslie, S. Godden, M. Capel, J. E. Santos, M. W. Overton, and T. F. Duffield. 2012. The association of serum metabolites in the transition period with milk production and early-lactation reproductive performance. J. Dairy Sci. 95:1301-1309.

Contreras, G. A., N. J. O'Boyle, T. H. Herdt, and L. M. Sordillo. 2010. Lipomobilization in periparturient dairy cows influences the composition of plasma nonesterified fatty acids and leukocyte phospholipid fatty acids. J. Dairy Sci. 93:2508-2516.

Dohoo, I. R., and S. W. Martin. 1984. Subclinical ketosis: Prevalence and associations with production and disease. Can. J. Comp. Med. 48:1-5.

Duffield, T. 2000. Subclinical ketosis in lactating dairy cattle. Vet. Clin. North Am. Food Anim. Pract. 16:231-253. 
Duffield, T. F., K. D. Lissemore, B. W. McBride, and K. E. Leslie. 2009. Impact of hyperketonemia in early lactation dairy cows on health and production. J. Dairy Sci. 92:571-580.

Duffield, T. F., D. Sandals, K. E. Leslie, K. Lissemore, B. W. McBride, J. H. Lumsden, P. Dick, and R. Bagg. 1998. Efficacy of monensin for the prevention of subclinical ketosis in lactating dairy cows. J. Dairy Sci. 81:2866-2873.

Geishauser, T., K. Leslie, T. Duffield, and V. Edge. 1997. Evaluation of aspartate transaminase activity and beta-hydroxybutyrate concentration in blood as tests for prediction of left displaced abomasum in dairy cows. Am. J. Vet. Res. 58:1216-1220.

Geishauser, T., K. Leslie, D. Kelton, and T. Duffield. 2001. Monitoring for subclinical ketosis in dairy herds. Compend. Contin. Educ. Pract. Vet. 23:S65-S71.

Goldhawk, C., N. Chapinal, D. M. Veria, D. M. Weary, and M. A. G. von Keyserlingk. 2009. Prepartum feeding behavior is an early indicator of subclinical ketosis. J. Dairy Sci. 92:4971-4977.

Gordon, J. L., S. J. LeBlanc, and T. F. Duffield. 2013. Ketosis treatment in lactating dairy cattle. Vet. Clin. North Am. Food Anim. Pract. 29:433-445.

Gordon, J. L., S. J. LeBlanc, L. Neuder, T. H. Herdt, D. F. Kelton, and T. F. Duffield. 2012. Efficacy of a combination butaphosphan and cyanocobalamin product and insulin for ketosis treatment. J. Dairy Sci. 95(Suppl. 2):177. (Abstr.)

Grummer, R. R. 1995. Impact of changes in organic nutrient metabolism on feeding the transition dairy cow. J. Anim. Sci. 73:28202833.

Guard, C. L. 2008. The costs of common diseases of dairy cattle. Pages 695-700 in Proc. Calif. Vet. Conf., San Diego, CA. Advanstar Communications, Lenexa, KS.

Hammon, D. S., I. M. Evjen, T. R. Dhiman, J. P. Goff, and J. L. Walters. 2006. Neutrophil function and energy status in Holstein cows with uterine health disorders. Vet. Immunol. Immunopathol. 113:21-29.

Herdt, T. H. 2000. Ruminant adaptation to negative energy balance. Influences on the etiology of ketosis and fatty liver. Vet. Clin. North Am. Food Anim. Pract. 16:215-230.

Hooijer, G. A., R. B. F. Lubbers, B. J. Ducro, J. A. M. van Arendonk, L. M. T. E. Kaal-Lansbergen, and T. van der Lende. 2001. Genetic parameters for cystic ovarian disease in Dutch black and white dairy cattle. J. Dairy Sci. 84:286-291.

Huzzey, J. M., D. M. Veira, D. M. Weary, and M. A. G. von Keyserlingk. 2007. Prepartum behavior and dry matter intake identify dairy cows at risk for metritis. J. Dairy Sci. 90:3220-3233.

Ijaz, A., M. L. Fahning, and R. Zemjanis. 1987. Treatment and control of cystic ovarian disease in dairy cattle. Br. Vet. J. 143:226-237.

LeBlanc, S. J., K. E. Leslie, and T. F. Duffield. 2005. Metabolic predictors of displaced abomasum in dairy cattle. J. Dairy Sci. 88:159-170.

López-Gatius, F. 2003. Is fertility declining in dairy cattle? A retrospective study in northeastern Spain. Theriogenology 60:89-99.

McArt, J. A. A., D. V. Nydam, and G. R. Oetzel. 2012. Epidemiology of subclinical ketosis in early lactation dairy cattle. J. Dairy Sci. 95:5056-5066.

McArt, J. A. A., D. V. Nydam, G. R. Oetzel, T. R. Overton, and P. A. Ospina. 2013. Elevated non-esterified fatty acids and $\beta$-hydroxybutyrate and their association with transition dairy cow performance. Vet. J. 198:560-570.

NRC. 2001. Nutrient Requirements of Dairy Cattle. 7th ed. Natl. Acad. Press, Washington, DC.

Oetzel, G. R., and B. E. Miller. 2012. Effect of oral calcium bolus supplementation on early-lactation health and milk yield in commercial dairy herds. J. Dairy Sci. 95:7051-7065.

Ospina, P. A., J. A. A. McArt, T. R. Overton, T. Stokol, and D. V. Nydam. 2013. Using nonesterified fatty acids and $\beta$-hydroxybutyrate concentrations during the transition period for herd-level monitoring of increased risk of disease and decreased reproductive and milking performance. Vet. Clin. North Am. Food Anim. Pract. $29: 387-412$.
Ospina, P. A., D. V. Nydam, T. Stokol, and T. R. Overton. 2010a. Associations of elevated nonesterified fatty acids and beta-hydroxybutyrate concentrations with early lactation reproductive performance and milk production in transition dairy cattle in the Northeastern United States. J. Dairy Sci. 93:1596-1603.

Ospina, P. A., D. V. Nydam, T. Stokol, and T. R. Overton. 2010b. Evaluation of nonesterified fatty acids and $\beta$-hydroxybutyrate in transition dairy cattle in the northeastern United States: Critical thresholds for prediction of clinical diseases. J. Dairy Sci. 93:546-554.

Overton, M., and J. Fetrow. 2008. Economics of postpartum uterine health. Pages 39-43 in Proc. Dairy Cattle Reprod. Counc. Annu. Meet., Omaha, NE.

Raizman, E. A., and J. E. Santos. 2002. The effect of left displacement of abomasum corrected by toggle-pin suture on lactation, reproduction, and health of Holstein dairy cows. J. Dairy Sci. $85: 1157-1164$.

Roberts, T., N. Chapinal, S. J. Leblanc, D. F. Kelton, J. Dubuc, and T. F. Duffield. 2012. Metabolic parameters in transition cows as indicators for early-lactation culling risk. J. Dairy Sci. 95:30573063

Rollin, E., R. D. Berghaus, P. Rapnicki, S. M. Godden, and M. W. Overton. 2010. The effect of injectable butaphosphan and cyanocobalamin on postpartum serum $\beta$-hydroxybutyrate, calcium, and phosphorus concentrations in dairy cattle. J. Dairy Sci. 93:978 987.

Seifi, H. A., S. J. Leblanc, K. E. Leslie, and T. F. Duffield. 2011. Metabolic predictors of post-partum disease and culling risk in dairy cattle. Vet. J. 188:216-220.

Shaver, R. D. 1997. Nutritional risk factors in the etiology of left displaced abomasum in dairy cows: a review. J. Dairy Sci. 80:24492453

St-Pierre, N., and B. Cobanov. 2014. Sesame. Accessed Jul. 23, 2014. www.sesamesoft.com.

Ster, C., M. C. Loiselle, and P. Lacasse. 2012. Effect of postcalving serum nonesterified fatty acids concentration on the functionality of bovine immune cells. J. Dairy Sci. 95:708-717.

Sterner, K. E., J. Grymer, P. C. Bartlett, and M. J. Miekstyn. 2008 Factors influencing the survival of dairy cows after correction of left displaced abomasum. J. Am. Vet. Med. Assoc. 232:1521-1529.

Stokes, S. R., and J. P. Goff. 2001. Case study: Evaluation of calcium propionate and propylene glycol administered into the esophagus of dairy cattle at calving. Prof. Anim. Sci. 17:115-122.

Suriyasathaporn, W., C. Heuer, E. N. Noordhuizen-Stassen, and Y. H. Schukken. 2000. Hyperketonemia and the impairment of udder defense: a review. Vet. Res. 31:397-412.

US Department of Labor. 2014. Accessed Jul. 23, 2014. www.bls.gov/ data/inflation_calculator.htm.

USDA-Agricultural Marketing Service. 2014. Accessed Jul. 23, 2014 www.ams.usda.gov.

USDA-National Agricultural Statistics Service. 2014. Accessed Jul. 23, 2014. www.nass.usda.gov.

Wagner, S. A., and D. E. Schimek. 2010. Evaluation of the effect of bolus administration of $50 \%$ dextrose solution on measures of electrolyte and energy balance in postpartum dairy cows. Am. J. Vet. Res. 71:1074-1080.

Walsh, R. B., J. S. Walton, D. F. Kelton, S. J. LeBlanc, K. E. Leslie, and T. F. Duffield. 2007. The effect of subclinical ketosis in early lactation on reproductive performance of postpartum dairy cows. J. Dairy Sci. 90:2788-2796.

Zarrin, M., O. Wellnitz, H. A. van Dorland, and R. M. Bruckmaier. 2014a. Induced hyperketonemia affects the mammary immune response during lipopolysaccharide challenge in dairy cows. J. Dairy Sci. 97:330-339.

Zarrin, M., O. Wellnitz, H. A. van Dorland, J. J. Gross, and R. M. Bruckmaier. 2014b. Hyperketonemia during lipopolysaccharide-induced mastitis affects systemic and local intramammary metabolism in dairy cows. J. Dairy Sci. 97:3531-3541. 